\title{
Citrus psorosis and Mirafiori lettuce big-vein ophiovirus coat proteins localize to the cytoplasm and self interact in vivo
}

\author{
Eduardo José Peña ${ }^{\mathrm{b}, 1}$, Gabriel Robles Luna ${ }^{\mathrm{a}, 1}$, María Cecilia Zanek ${ }^{\mathrm{a}}$, María Belén Borniego ${ }^{\mathrm{a}}$, \\ Carina Andrea Reyes ${ }^{a}$, Manfred Heinlein ${ }^{\mathrm{b}}$, María Laura García ${ }^{\mathrm{a}, *}$ \\ a Instituto de Biotecnología y Biología Molecular, CCT-La Plata CONICET, Fac. Cs. Exactas, U.N.L.P., La Plata, Argentina \\ ${ }^{\mathrm{b}}$ Institut de Biologie Moléculaire des Plantes du CNRS (UPR 2357), Université de Strasbourg, 12 rue du Général Zimmer, 67084 Strasbourg CEDEX, France
}

\section{A R T I C L E I N F O}

\section{Article history:}

Received 22 March 2012

Received in revised form 1 August 2012

Accepted 8 August 2012

Available online 18 August 2012

\section{Keywords:}

Citrus psorosis virus

Mirafiori lettuce big-vein virus

Ophioviridae

Coat protein

Subcellular localization

Protein interaction

FRET

FLIM

Immunoprecipitation

\begin{abstract}
A B S T R A C T
Citrus psorosis (CPsV) and Mirafiori lettuce big-vein virus (MiLBVV) belong to the family Ophioviridae plant viruses with filamentous nucleocapsids and segmented genomes of negative polarity, causing the worldwide distributed citrus psorosis and lettuce big-vein diseases, respectively. To gain insight into the replication cycle of these viruses, the subcellular localization of the viral coat proteins (CP) was studied. Immunoblot analysis of fractionated extracts derived from natural and experimental infected hosts indicated that the $\mathrm{CP}$ of $\mathrm{CPsV}$ occurs in the soluble cytoplasmic fraction. The cytoplasmic localization of this protein was confirmed by confocal microscopy of fluorescent protein (FP)-tagged CP following its expression in either CPsV-infected and healthy Citrus sinensis plants or in Nicotiana benthamiana plants. The same localization was observed for FP-tagged CP of MiLBVV. The CPs of CPsV and MiLBBV can undergo homologous and heterologous interactions as revealed by fluorescent lifetime imaging microscopy and co-immunoprecipitation analysis. A putative leucine zipper motif that is conserved among ophiovirus CP sequences may account for these interactions.
\end{abstract}

(C) 2012 Elsevier B.V. All rights reserved.

\section{Introduction}

Ophioviruses are causal agents of severe diseases in citrus, lettuce and ornamental plants. Citrus psorosis virus ( $\mathrm{CPsV})$, the causal agent of psorosis disease, affects most citrus varieties in many countries of America, Africa and the Mediterranean Basin (Roistacher, 1991, 1993). In Argentina and Uruguay, the disease is naturally spread by an unknown vector and produces important economical losses (Anderson, 2000; Campiglia et al., 1976; Danós, 1990). Big-vein disease caused by Mirafiori lettuce big-vein virus (MiLBVV) is one of the most important diseases in lettuce affecting production in cool and wet soil areas (Falk, 1997). Information about ophiovirus genes and putative proteins is derived from genome sequences available for CPsV (Naum-Ongania et al.,

\footnotetext{
Abbreviations: CPsV, Citrus psorosis virus; MiLBVV, Mirafiori lettuce big-vein virus; $\mathrm{CP}$, coat protein; $\mathrm{CP}^{\mathrm{CPSV}}, \mathrm{CP}$ of $\mathrm{CPsV}$; $\mathrm{CP}^{\mathrm{MiLBBV}}, \mathrm{CP}$ of MiLBVV; CLSM, confocal laser scanning microscopy; FRET, fluorescence resonance energy transfer; FLIM, fluorescent lifetime imaging microscopy.

* Corresponding author at: Instituto de Biotecnología y Biología Molecular(IBBM), CCT-La Plata, CONICET-UNLP, Calles 49 y 115, 1900 La Plata, Argentina.

Tel.: +54 221 4229777; fax: +542214229777.

E-mail address: garcia_m@biol.unlp.edu.ar (M.L. García).

1 Equal contributors.
}

2003; Sanchez de la Torre et al., 1998, 2002), MiLBVV (van der Wilk et al., 2002), and Lettuce ring necrosis virus (LRNV) (Torok and Vetten, 2004). The ophiovirus genome consists of three or four ssRNA segments with negative or ambisense polarity (Garcia et al., 1994; Milne et al., 2003; van der Wilk et al., 2002). The genomic complementary strand of the CPsV RNA 1 encodes a $24 \mathrm{kDa}$ polypeptide of unknown function and, separated by an intergenic region, the putative $280 \mathrm{kDa}$ RNA-dependent RNA polymerase (RdRp) (Naum-Ongania et al., 2003). RNA 2 contains one ORF encoding a polypeptide of $54 \mathrm{kDa}$ of unknown function (Sanchez de la Torre et al., 2002), and RNA 3 encodes the coat protein (CP) of $48.6 \mathrm{kDa}$ (named here $\mathrm{CP}^{\mathrm{CPsV}}$ ) (Sanchez de la Torre et al., 1998), both in the complementary strand. MiLBVV has a similar genome organization, encoding a putative $\mathrm{CP}$ of $48.5 \mathrm{kDa}$ (named here $\mathrm{CP}^{\mathrm{MiLBVV}}$ ) in RNA 3, but possesses a fourth genomic RNA segment (RNA 4) (van der Wilk et al., 2002). In addition to the full genome sequences of CPsV, MiLBVV, and LRNV, databases contain the CP sequences of several CPsV and MiLBVV isolates and of other ophiovirus species, such as Tulip mild mottle mosaic virus (TMMMV), Freesia sneak virus (FreSV) and Ranunculus white mottle virus (RWMV). MiLBVV, TMMMV, FreSV and LRNV are transmitted by Olpidium brassicae (Bos and Huijberts, 1996; Lot et al., 2002; Morikawa et al., 1995; van Dorst, 1975), whereas the vectors of CPsV and RWMV are still unknown. 
The cell biology of ophiovirus infection is still in its infancy. There is only scant information about the functions of ophiovirus proteins, their subcellular localization and their interaction with plant proteins. Ophiovirus replication may occur in the cytoplasm as would be inferred from the finding that RWMV particles were observed in the cytoplasm of infected Nicotiana clevelandii parenchyma cells (Vaira et al., 1997), but there are no further data from other members of this family. Here we used subcellular fractionation coupled to immunoblot analysis as well as confocal laser scanning microscopy (CLSM) of GFP-tagged proteins to determine the subcellular localization of $\mathrm{CP}^{\mathrm{CPsV}}$ and $C \mathrm{P}^{\mathrm{MiLBBV}}$. Our results indicate that the CPs of these viruses indeed accumulate in the cytoplasm. Moreover, the CPs can undergo homologous and heterologous interactions as is shown by the measurement of fluorescence resonance energy transfer (FRET) and by the results of co-immunoprecipitation assays. Bioinformatic analysis of ophiovirus CP sequences indicates the presence of leucine zipper motifs that could be implicated in $\mathrm{CP}-\mathrm{CP}$ interactions and critical viral functions such as in cell-to-cell movement, encapsidation, and nucleic acid binding. The subcellular localization of ophiovirus coat proteins and their homologous and heterologous interactions are discussed in the context of ophiovirus encapsidation and virus-vector interaction.

\section{Materials and methods}

\subsection{Virus isolates and hosts inoculation}

Young leaves of sweet orange plants (Citrus sinensis (L.) Osb) systemically infected with CPsV CPV-4 isolate from Florida (USA) (Garnsey and Timmer, 1980) were used for subcellular fractionation analysis and as source of virus for mechanical inoculation of the local and systemic herbaceous hosts, Chenopodium quinoa and Gomphrena globosa respectively. Leaves of lettuce plants
(Lactuca sativa) infected with the MiLBVV-LP2 isolate from La Plata, Argentina (Barcala Tabarrozzi et al., 2010) were used for total RNA extraction and cloning of the CPMiLBVV.

\subsection{Plasmid constructs and bacterial strains}

For use as immunogens, $\mathrm{CP} C \mathrm{CPV}$ and $54 \mathrm{~K}$ proteins were expressed in bacteria. Expression plasmids pET19b-CP and pET30a-54k were produced by $\mathrm{PCR}$ cloning of the full-length ORFs for $\mathrm{CP}^{\mathrm{CPsV}}$ and $54 \mathrm{~K}$ protein into plasmids pET19b and pET30a (Novagen), respectively. Plasmid pET30a-54K encodes the $54 \mathrm{~K}$ protein in fusion to a $6 \mathrm{xHis}-$ tail at its $\mathrm{N}$-terminus. The recombinant plasmids were transferred to Escherichia coli BL21(DE3)-CodonPlus-RIL by electroporation. For stable expression in Nicotiana benthamiana plants, plasmids p35SGUSINT/CP and p35SGUSINT/54K, bearing the CPCPsV and 54K ORF, respectively (Zanek et al., 2008), were used (Fig. 1A). Both plasmids were transferred to A. tumefaciens LBA4404 by electroporation. For transient expression in plant tissues, the complete ORF for unfused $C P^{C P s V}$ was cloned into the binary vector pGD (Goodin et al., 2002) resulting in plasmid pGD-CPCPsV (Fig. 1B). To express C-terminally tagged fluorescent protein (FP) fusions of $\mathrm{CP}^{\mathrm{CPsV}}$ and $\mathrm{CP}^{\mathrm{MiLBVV}}$, the respective ORFs without the stop codons were cloned into pCR8/GW/TOPO (Invitrogen). For N-terminal fusions a reverse PCR primer containing a stop codon was used. The resulting entry plasmids were digested with Xhol and recombined with destination vectors pGWB11 for FLAG tag fusions (Nakagawa et al., 2007) (Fig. 1C and D) and pB7WGF2, pB7RWG2 and pB7FWG2 (Karimi et al., 2002) for N-terminal fusions to eGFP or for C-terminal fusions to mRFP and eGFP respectively (Fig. 1E-J), using LR clonase mix (Invitrogen) according to the instructions of the manufacturer. For all constructs the correct cloning and insert orientations were confirmed by sequencing. Verified constructs were transferred to $A$. tumefaciens strain GV3101 by electroporation. Primer sequences are available upon request.

\section{A) p35SGUSINT-ORF CPsV}

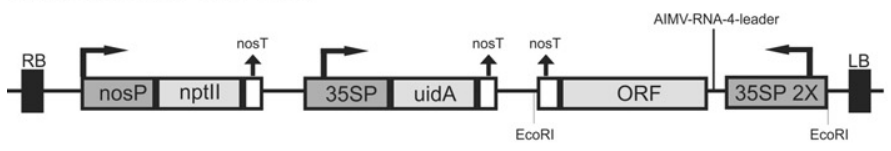

C) pGWB-54K:FLAG

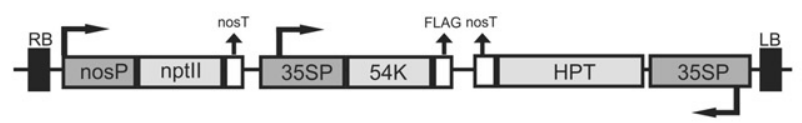

E) pB7-CP ${ }^{\text {CPsv }}:$ eGFP

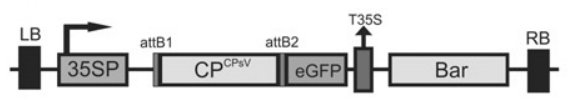

F) pB7-eGFP:CP CPSV $^{\text {CPV }}$

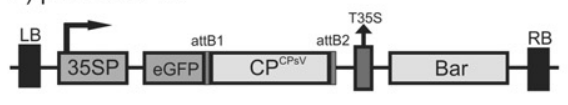

G) pB7-CP ${ }^{\mathrm{CPs} V}: \mathrm{mRFP}$

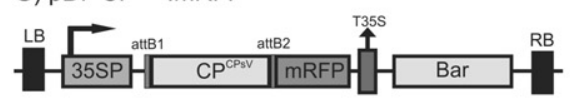

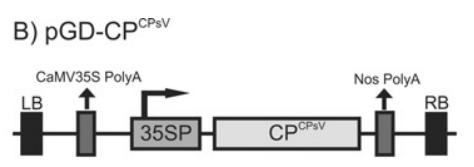

D) pGWB-55K:FLAG

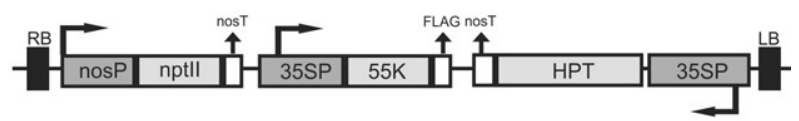

H) pB7-CP ${ }^{\text {MLBw }}:$ eGFP
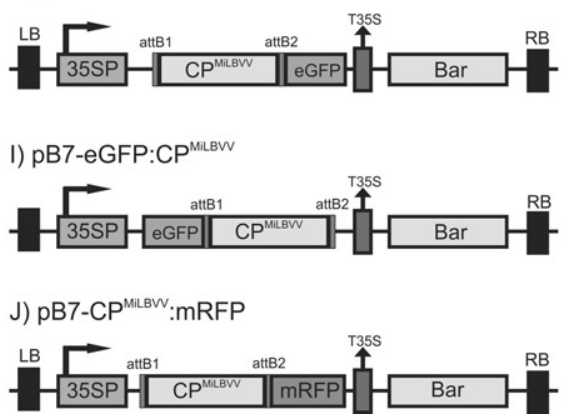

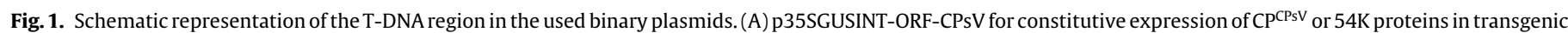

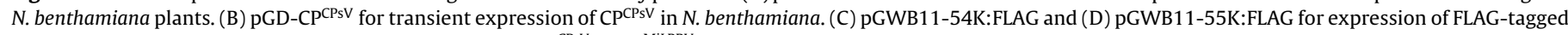

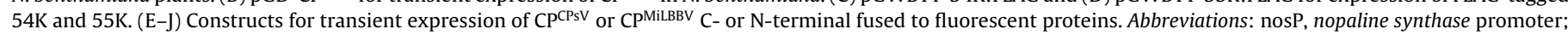

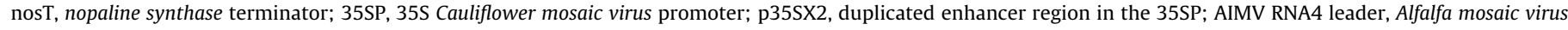

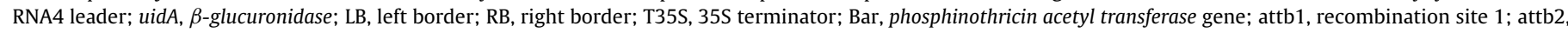
recombination site 2 ; HPT, hygromycin phosphotransferase gene. 


\subsection{Protein synthesis and production of anti-CP and anti-54K} sera

Antibodies against the $\mathrm{CP}$ and $54 \mathrm{~K}$ proteins of $\mathrm{CPsV}$ were produced by immunization of rabbits with proteins expressed in $\mathrm{E}$. coli BL21(DE3)-CodonPlus-RIL. A 1/10 dilution from an overnight bacterial culture transformed with respective plasmids (pET19b-CP, pET30a-54k) was used to induce expression of the polypeptide with $1.0 \mathrm{mM}$ IPTG at $37^{\circ} \mathrm{C}$ for $3 \mathrm{~h}$. CP inclusion bodies were extracted from lysed cells by sonication and lysozyme incubation. After washing, the inclusion bodies containing a high CP concentration were resuspended and used as immunogen. The His-tagged 54K protein was purified by affinity column chromatography using a Ni-NTA His.Bind ${ }^{\circledR}$ Resin (Novagen) under denaturing conditions after extraction with $6 \mathrm{M}$ guanidinium chloride. Protein samples were dialyzed against PBS buffer to eliminate remaining urea. For each protein, three rabbits were inoculated by intraperitoneal and intramuscular injections with emulsions prepared in complete Freund adjuvant (SIGMA). In addition, intradermal booster injections were made with the immunogens in incomplete Freund adjuvant emulsion $(1: 1, \mathrm{vol} / \mathrm{vol})$. The rabbits were bled 10 days after each injection to test the antisera by immunoblot analysis using the proteins purified from $E$. coli.

\subsection{Protein analysis}

Protein amounts were determined by Bradford assays or by SDS-PAGE using $10 \%$ polyacrylamide gels followed by Coomassie blue staining. For immunoblot assays to detect specific proteins, the electrophoretically separated proteins were transferred to PVDF membrane (Hybond-P, Amersham Pharmacia, Biotech) and probed with specific antibodies. The $\mathrm{CP}^{\mathrm{CPSV}}$ and $54 \mathrm{~K}$ proteins were detected with anti-54K and anti $\mathrm{CP}^{\mathrm{CPsV}}$ antisera at 1:250 and 1:50 dilution respectively, followed by anti-rabbit-IgG conjugated to alkaline phosphatase (GibcoBRL, Life Technologies). Expression levels of $\mathrm{CP}^{\mathrm{CPsV}}$ protein were also determined by TAS-ELISA as previously described (Zanek et al., 2006). eGFP fusion proteins were analyzed using anti-GFP (BD Living Colors A.v. Monoclonal Antibody (JL-8)) and horseradish peroxidase-conjugated goat anti-mouse antibody (BioRad, CA, USA) followed by chemiluminescent detection (GE, ECL Plus Western Blotting Detection Reagents).

\subsection{Production of transgenic $N$. benthamiana plants and transient expression}

Transgenic $N$. benthamiana plants were generated by infection of leaf disks with A. tumefaciens LBA4404 carrying p35SGUSINT/CP or p35SGUSINT/54 according to Horsch and colleagues (Horsch et al., 1985). For transient protein expression in $N$. benthamiana, A. tumefaciens cells were harvested by centrifugation, resuspended in water to a final $\mathrm{OD}_{600 \mathrm{~nm}}$ of 0.2 and injected into the abaxial side of the leaf, using a syringe without needle. For transient eGFP:CPCPsV expression in infected and healthy sweet orange leaves, the agrobacteria were injected with a higher concentration $\left(\mathrm{OD}_{600 \mathrm{~nm}}=1.0\right)$ into the abaxial side of detached, fully expanded young leaves of medium size (about $7 \mathrm{~cm}$ long). The treated leaves were kept for 3-7 days post agroinfiltration (dpai) at $22-24{ }^{\circ} \mathrm{C}$ in a moist chamber with $16 \mathrm{~h}$ light $/ 8 \mathrm{~h}$ dark illumination.

\subsection{Subcellular fractionation}

Infected sweet orange leaves with symptoms of CPsV infection (spot and flecking) and C. quinoa and G. globosa tissue bearing local and systemic chlorotic lesions were used for subcellular fractionation according to Rouleau and colleagues (Rouleau et al., 1993), with modifications. $1.0 \mathrm{~g}$ of fresh material was homogenized in $10 \mathrm{ml}$ homogenization buffer (HB) $(0.4 \mathrm{M}$ sucrose, $10 \mathrm{mM} \mathrm{KCl}$, $5.0 \mathrm{mM} \mathrm{MgCl}_{2}$, $50 \mathrm{mM}$ Tris- $\mathrm{HCl} \mathrm{pH} 8.2,20 \%$ glycerol, $10 \mathrm{mM} \beta-$ mercaptoethanol and 1.0 mM PMSF) and filtered through miracloth to retain the cell wall fraction (CW). The filtrate was centrifuged $(1000 \times g)$ to recover the pellet fraction P1 (nucleus/chloroplast). The supernatant solution (S1) was re-centrifuged $(30,000 \times g)$ to generate a new supernatant fraction, S30 (cytoplasmic) and a pellet fraction P30 (microsomal). P1 and P30 fractions were washed in HB and resuspended in $1 \mathrm{ml}$ ESB buffer (4.5\% SDS, 9.0 M urea, $75.0 \mathrm{mM}$ Tris- $\mathrm{HCl}, \mathrm{pH} 6.8,7.5 \% \beta$-mercaptoethanol) per g of starting material. The CW fraction was resuspended in $1.0 \mathrm{ml} \mathrm{HB}$ containing $1 \%$ Triton X-100 and stirred for $1 \mathrm{~h}$ at $4{ }^{\circ} \mathrm{C}$ to extract any membranous fraction loosely bound to the fibrous material. The cell wall fiber was recovered by filtration and resuspended in $1 \mathrm{ml}$ ESB per $\mathrm{g}$ of starting material. Each fraction was subjected to immunoblot analysis with $\mathrm{CP}$ antibody. As a consequence of the fractionation procedure, the $S 30$ fraction is 10 -fold diluted as compared to P1, P30 and CW fractions. To allow comparison between infected and noninfected samples, equivalent amounts of starting material were loaded into each lane.

\subsection{Fluorescence microscopy}

CLSM was performed using a Zeiss LSM510 microscope with a C-Apo-chromat (63/1.2 W Korr) water objective lens in multitrack mode, excitation/emission wavelengths of $488 \mathrm{~nm} / 505-550 \mathrm{~nm}$ for eGFP and 561/575-615 nm for mRFP, and LSM510 version 2.8 software. Alternatively, a Leica TCS SP5 II microscope was used. This microscope was equipped with a HCX PL APO CS 63.0x 1.40 oil UV objective, excitation/emission wavelength of 488/524-550 nm for eGFP and of 543/566-634 nm for mRFP, and LAS AF version 2.2.1 4842 software. Images were processed with ImageJ software. GFP fluorescence lifetime was measured using a Lambert Instruments Fluorescence lifetime Attachment (LIFA), mounted on a Nikon TE2000 inverted microscope with a $63 \times 1.4$ oil objective and using excitation/emission wavelengths of 460-500/510-560 nm for GFP and of 550-600/615-665 nm for RFP. FLIM images were acquired and processed with LI-FLIM software version 1.2.9.117 (Lambert Instruments). ANOVA statistical analysis was performed using the Turkey test $(\alpha=0.01)$. FRET efficiency was calculated as: $E=1-\tau_{\mathrm{DA}} / \tau_{\mathrm{D}} \times 100$, where $\tau_{\mathrm{DA}}$ is the lifetime of the donor in the presence of the acceptor and $\tau_{\mathrm{D}}$ is the lifetime of the donor in the absence of the acceptor.

\subsection{Co-immunoprecipitation assay}

Co-immunoprecipitation assays were performed with RFPTrap_A as described by the manufacturer (Chromotek, Germany). Total plant protein was extracted with modified lysis buffer $(10 \mathrm{mM}$ Tris- $\mathrm{HCl} \mathrm{pH} 7.5,0.5 \mathrm{mM}$ EDTA, $150 \mathrm{mM} \mathrm{NaCl}, 0.5 \%$ Tween 20) containing a protease inhibitor cocktail $(0.5 \mathrm{mM}$ PMSF, $2 \mu \mathrm{g} / \mathrm{ml}$ Pepstatin, $10 \mu \mathrm{g} / \mathrm{ml}$ Leupeptin-hemisulfate, $10 \mu \mathrm{g} / \mathrm{ml}$ Trypsin inhibitor from egg white, $10 \mu \mathrm{g} / \mathrm{ml}$ Trypsin inhibitor from soybean). Protein extracts (Input, I) were diluted with lysis buffer without Tween 20 (dilution buffer) to reduce the detergent concentration down to $0.15 \%$. Extracts were incubated with $20 \mu \mathrm{l}$ of RFP-Trap_A slurry for $30 \mathrm{~min}$ at room temperature. After centrifugation at $2700 \times \mathrm{g}$ and $4{ }^{\circ} \mathrm{C}$ for $2 \mathrm{~min}$, the supernatant was discarded, and the remaining agarose beads were washed twice with ice-cold dilution buffer. Then, $20 \mu \mathrm{l}$ of glycine $0.2 \mathrm{M}$ pH 2.5 , were added to the agarose beads, neutralized with $2 \mu \mathrm{l}$ of Tris- $\mathrm{HCl} 1 \mathrm{M}, \mathrm{pH} 10$ at room temperature, boiled for $10 \mathrm{~min}$ in $2 \times$ sample buffer, and centrifuged at $2700 \times g$ for $2 \mathrm{~min}$ (Bound, B). Precipitated protein samples were separated by SDS-PAGE, transferred to PVDF membrane and probed with anti-GFP JL- 8 monoclonal antibody. After stripping the membranes according to manufacturer instructions 
(Amersham Biosciences, England), they were re-probed with antimRFP 3F5 monoclonal antibody (Chromotek, Germany).

\subsection{Bioinformatic analysis}

ClustalW sequence alignment of ophiovirus CP amino acid sequences from different isolates was performed with MEGA version 4.0 (Tamura et al., 2007). Accession numbers for CPsV were AAC41022, YP_089664, AAT72910, CAJ43825; for FreSV ACR56715, ACY40696, ABI33222; for LRNV AAT09112, YP_053239; for RWMV AAT08132; for TMMMV AAT08133; and for MiLBVV ABG67683, ADC55528, AAW82345, AAW82346, AAW82347, AAW82348, ABG67683, ABG67684 ABB04496, AAU12866, AAU12867, AAU12868, AAU12869, AAU12870, AAU12871, AAU12872, AAU12873, AAU12874, AAU12875, AAU12876, ADR31473, ADR31474, ADR31475, ADR31476, ADR31477, ADR31478, ADR31479, ADR31480, ADR31481, ADR31482, ADR31483, ADR31484, ABG67682, NP_848533, AAO49152, AAQ77398, AAQ77399, AAQ77400, AAQ77401, AF525936_4, ACX37416 and ACX37417. Sequence alignments using consensus sequences for each ophiovirus were obtained to show the region of interest. Motifs were analysed by MotifScan software, MyHits database (Hulo et al., 2008; Pagni et al., 2007). Subcellular localization was predicted using Psort (Nakai and Horton, 1999).

\section{Results}

\subsection{Test of antisera and selection of transgenic plants expressing the $C P$ and $54 K$ proteins of $C P S V$}

Newly generated anti-CP and anti-54K sera were tested in different dilutions against the specific $E$. coli- or plant-expressed proteins using immunoblot assays. Specific protein detection was achieved with a 1:50 dilution of the antiserum reacting specifically to CPCPsV (Fig. S1A) and with a 1:250 dilution of the antiserum against 54K (Fig. S1B). Transgenic $N$. benthamiana lines expressing the respective proteins were analyzed by TAS-ELISA and immunoblot assays. Lines CP:02 and 54:06 showing the highest expression levels for either $\mathrm{CP}^{\mathrm{CPsV}}$ or $54 \mathrm{~K}$ (Fig. S1C and D) were selected for subsequent experiments. The accumulation level of the $\mathrm{CP}$ produced in line CP:02 does not exceed the level produced during infection in $C$. quinoa, and the immunoreactive band for $\mathrm{CP}^{\mathrm{CPS} V}$ showed the same molecular weight irrespective whether isolated from plant or bacteria, indicating that the protein is not subject to major posttranslational modifications in plants.

\section{2. $C P^{C P s V}$ localizes in the cytoplasm of infected natural and} herbaceous hosts

The accumulation of $\mathrm{CP}^{\mathrm{CPsV}}$ during infection was analyzed by TAS-ELISA in time course experiments using inoculated C. quinoa and G. globosa plants. In leaves the protein was detected at 2 and 4 days post inoculation (dpi) reaching highest expression at $3-5 \mathrm{dpi}$ and $7 \mathrm{dpi}$, respectively (Fig. $2 \mathrm{~A}$ and B). After $15 \mathrm{dpi}, \mathrm{CP}^{\mathrm{CPsV}}$ was also detected in upper leaves of G. globosa (see Fig. 2B). Since the leaves are still asymptomatic at this stage of infection, the presence of the $\mathrm{CP}$ does not correlate with the formation of CPsV symptoms in this systemic host.

Next, we addressed the subcellular localization of the $\mathrm{CP}^{\mathrm{CPsV}}$ by subcellular fractionation followed by immunoblot analysis of the fractions. Taking the measured accumulation pattern in account, we chose the time of highest protein accumulation for this analysis ( $4 \mathrm{dpi}$ for $C$. quinoa; $7 \mathrm{dpi}$ for G. globosa). At this time, the CPCPsV was restricted to the enriched soluble cytoplasmic fraction (S30) since no signal was found in the enriched nucleus (P1), microsomal (P30), or cell wall (CW) fractions (Fig. 3A). The CPs of viruses that move cell-to-cell in a CP-dependent manner are often observed at or near the CW (e.g. potex and potyviruses; Rouleau et al., 1995; Rodriguez-Cerezo et al., 1997). Thus, the absence of $\mathrm{CPCPsV}^{\mathrm{C}}$ in the $\mathrm{CW}$ fraction could indicate that the $\mathrm{CP}$ of $\mathrm{CPSV}$ is dispensable for cell-to-cell movement. However, it is also possible that our assay was not sufficiently sensitive to detect the protein in this fraction.
A
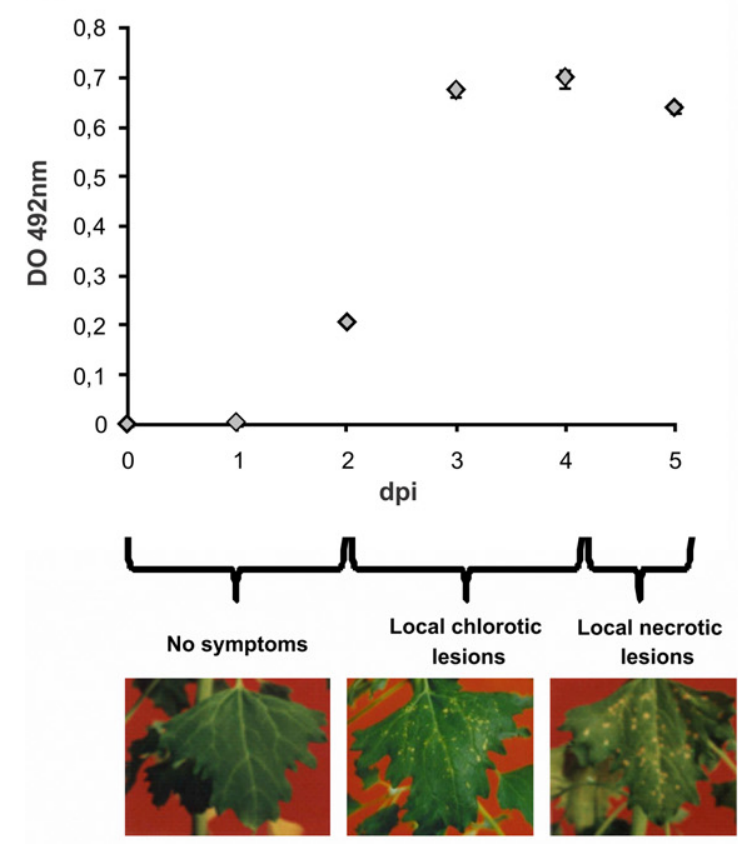

B
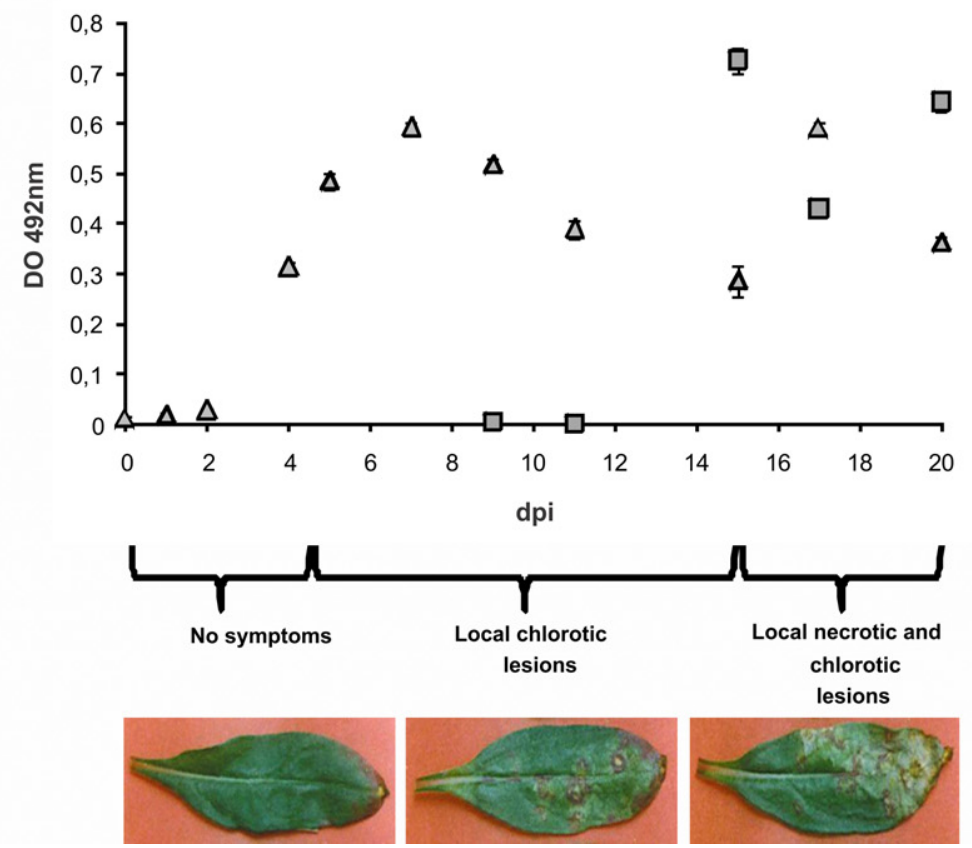

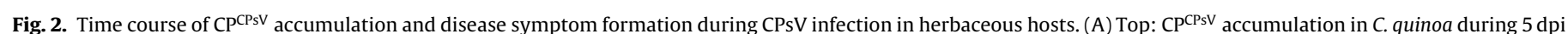

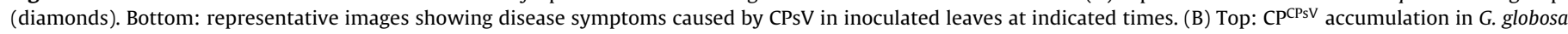

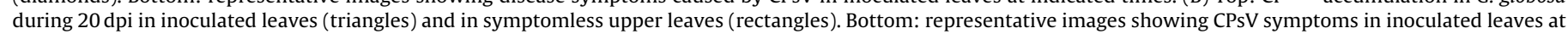
indicated times. 
A

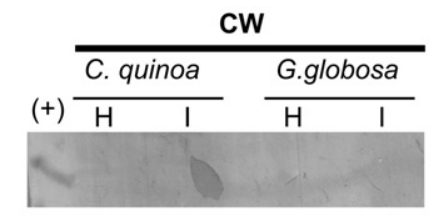

P1

\begin{tabular}{|c|c|c|}
\hline C. quinoa & C. sinensis & G. globosa \\
\hline $\mathrm{H}$ & $\mathrm{H}$ & $\mathrm{H}$ \\
\hline
\end{tabular}

$(+)$

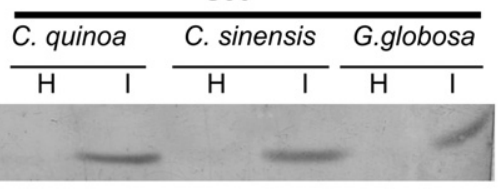

P30

(+) $\begin{array}{lllll}\mathrm{H} \quad \mathrm{I} & \mathrm{H} \quad \mathrm{H} \quad \mathrm{I}\end{array}$

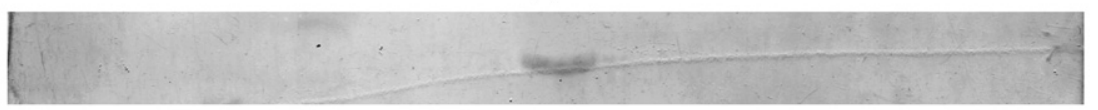

B

S30

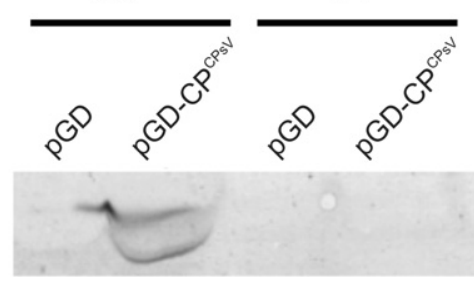

P30

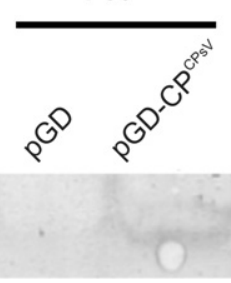

CW

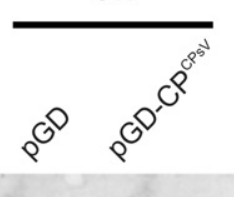

$(+)$

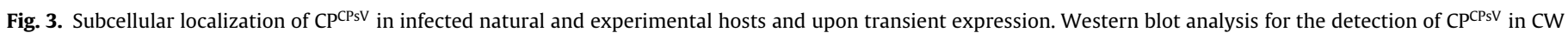

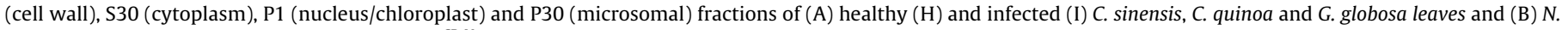
benthamiana leaves agroinfiltrated with $\mathrm{pGD}-\mathrm{CP}^{\mathrm{CPsV}}$ and with $\mathrm{pGD}$ plasmid as negative control. (+), total protein of partially purified CPsV virions as positive control.

Immunoblot analysis of subcellular fractions obtained from systemically infected leaves of the natural host $C$. sinensis confirmed the accumulation of $\mathrm{CP}$ in the S30 fraction, with no detectable $\mathrm{CP}$ present in other fractions. Due to the low total protein recovered after resuspension, the cell wall fraction of citrus leaves was not analyzed (Fig. 3A). Bioinformatic analysis using Psort (Nakai and Horton, 1999) predicted a cytoplasmic localization for the ophiovirus CPs (data not shown), which is consistent with these findings. Together, these results indicate that $\mathrm{CP} \mathrm{PPsV}^{\mathrm{C}}$ accumulates in the cytoplasm irrespective of infection in C. sinensis or G. globosa (systemic hosts), or in C. quinoa (local host).

\section{3. $C P^{C P S V}$ and $C P^{M i L B V V}$ accumulate in the cytoplasm upon ectopic expression}

\subsubsection{Transient and constitutive expression of $C P^{C P s V}$ in $N$. benthamiana}

To further characterize the $\mathrm{CP}{ }^{\mathrm{CPsV}}$, the protein was expressed in the absence of other viral proteins or RNAs. Upon transient expression in $N$. benthamiana, where expression levels were higher as compared to all the other assayed infected hosts (not shown), the protein was again detected exclusively in the S30 fraction (Fig. 3B). A CP double band has been occasionally detected in pGD-CPCPsV samples. We cannot rule out that this is due to partial proteolysis; however, the double band was not seen in other extracts derived from the same host but expressing CP fused to FPs (see Section 3.3.2). The CP also localizes in the S30 fraction of transgenic $N$. benthamiana line $\mathrm{CP}: 02$, which expresses the $\mathrm{CP} C \mathrm{CPV}$ constitutively (data not shown). These results indicate that $\mathrm{CP}^{\mathrm{CPsV}}$ localizes to the cytoplasm also upon transient overexpression, thus in the absence of other viral proteins.

\subsubsection{Localization of $C P^{C P S V}$ and $C P^{M i L B V V}$ tagged with fluorescent markers}

To confirm the above results and to increase the resolution of our subcellular analysis, the CPCPsV was transiently expressed as fluorescent protein (FP) fusion and visualized by CLSM in
$N$. benthamiana epidermal cells. The CP of MiLBVV (CPMiLBVV $)$ was included in this analysis. Both FP-tagged proteins showed a diffuse cytoplasmic pattern. Co-expression of eGFP-tagged $\mathrm{CP}^{\mathrm{CPsV}}$ or eGFP-tagged CPMiLBVV together with free mRFP (distributed in the cytoplasm and nucleus) resulted in the co-localization of red and green fluorescence signal in the cytoplasm but not in the nucleus, and in transvacuolar cytoplasmic strands both in central (Fig. 4A and $C$, arrows), and cortical views (Fig. $4 \mathrm{~B}$ and D). Expression of the CPs in fusion to mRFP (CPCPsV:mRFP and CPMiLBVV:mRFP) in $N$. benthamiana line 16c transgenic for the ER marker HDEL-GFP (Ruiz et al., 1998) led to visualization of the proteins in the cytoplasm near the cortical ER but did not reveal any co-localization with the tubular membrane network (Fig. S2). The same results were obtained irrespective whether the CPs were fused to eGFP or mRFP or whether fused at the N- or C-terminus (data not shown), indicating that the position and identity of the fluorophores did not influence the localization.

The subcellular localization of $\mathrm{CP}$ observed upon transient expression may be deceptive since during the infection the protein may interact with other viral and host proteins that modify its localization. Indeed, viral proteins may relocate when co-expressed with other viral proteins, which can reveal specific interactions (Boutant et al., 2010; Ribeiro et al., 2009). Although our subcellular fractionation of infected tissue showed that the $\mathrm{CP}^{\mathrm{CPsV}}$ is also cytoplasmic in the context of infection, we tested the localization of eGFP:CPCPsV or $\mathrm{CP}^{\mathrm{CPsV}}$ :eGFP proteins in the $N$. benthamiana line 54:06 (expressing $54 \mathrm{~K}$ protein, encoded in RNA2). We also tested the localization of Nor C-eGFP fusions of $\mathrm{CP}^{\mathrm{CPsV}}$ and $\mathrm{CP}^{\mathrm{MiLBVV}}$ upon coexpression with FLAG-tagged $54 \mathrm{~K}^{\mathrm{CPSV}}$ and $55 \mathrm{~K}^{\mathrm{MiLBVV}}$, respectively. However, in all these cases the $\mathrm{CP}$ proteins remained diffusively distributed in the cytoplasm (data not shown). These results confirm the cytoplasmic localization of $\mathrm{CP}$.

\subsubsection{Expression of eGFP:CPCPSV in infected C. sinensis}

C. quinoa and G. globosa are experimental hosts for the analysis of CPsV infections but are recalcitrant to the analysis of CPsV proteins by $A$. tumefaciens-mediated transient expression. 

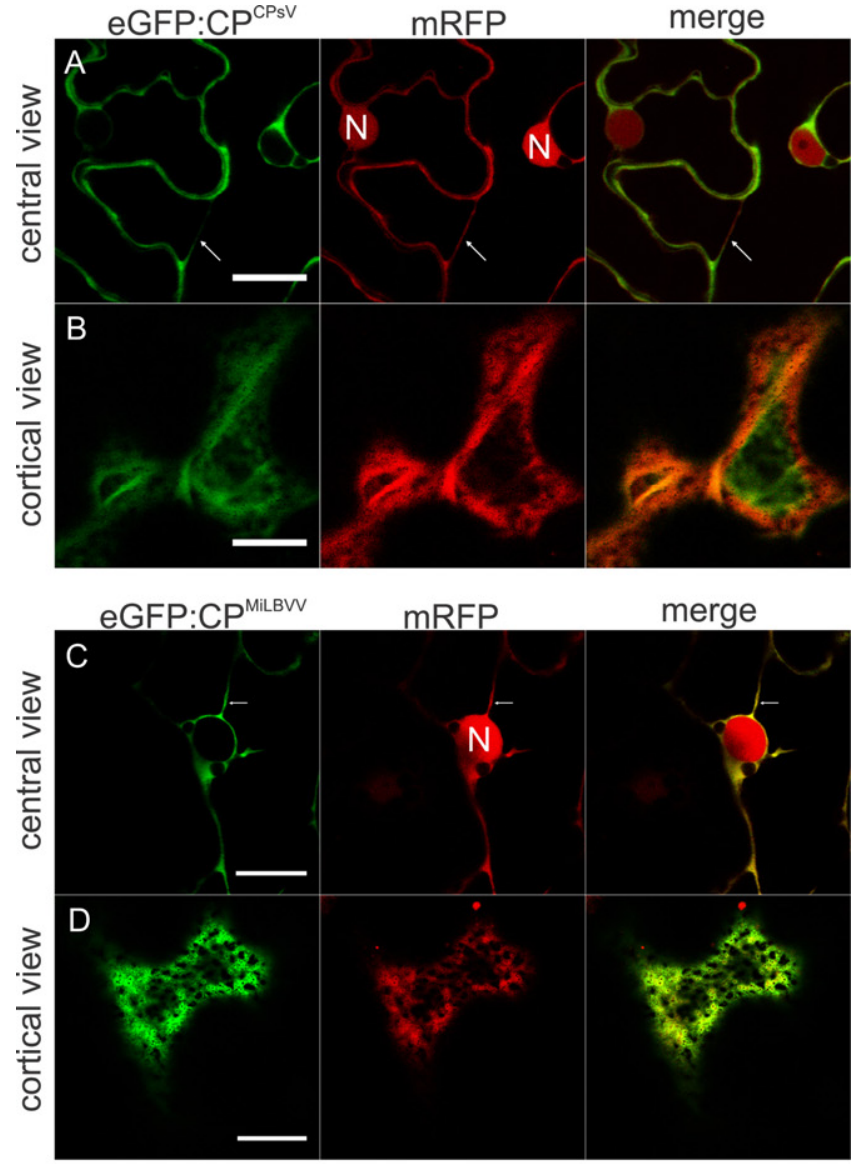

E I

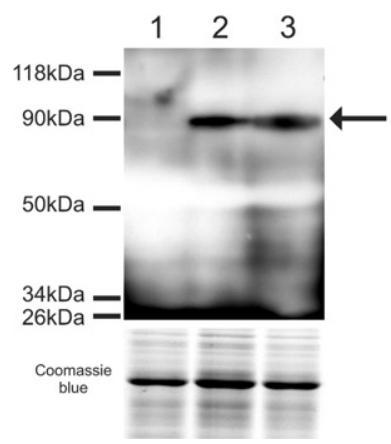

II

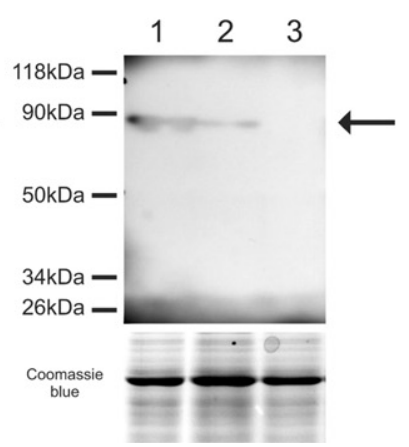

Fig. 4. Subcellular localization of fluorescent protein-tagged $C P^{C P s V}$ and $C P^{M i L B V V}$ (A and $\mathrm{B}$ ) Co-expression of eGFP:CPCPsV with free mRFP (cytoplasmic marker) at 48 hpai in $N$. benthamiana epidermal cell. (A) Central view; (B), cortical view. (C and D) Co-expression of eGFP:CPMiLBVV with free mRFP at 48 hpai in $N$. benthamiana epidermal cell. (C) Central view; (D) cortical view. N, nucleus. Arrows indicate transvacuolar cytoplasmic strands. Scale bar $=20 \mu \mathrm{m}$. (E) Western blot analysis of total protein extracts from $N$. benthamiana expressing eGFP fusions at 3 dpai. Panel I: lane 1 : water infiltrated leaves (-); lane 2 , eGFP:CPCPsV ; lane $3, C^{C P s V}$ :eGFP. Panel II: lane 1, eGFP:CPMiLBVV; lane 2, CPMiLBVV $:$ eGFP; lane 3, water infiltrated leaves (-).

$N$. benthamiana plants are better suited for transient expression analysis but show only local and asymptomatic infection upon inoculation with CPsV. To investigate the localization of the $\mathrm{CP}^{\mathrm{CPsV}}$ in the natural host, eGFP:CPCPsV was transiently expressed by agroinfiltration in healthy and infected $C$. sinensis plants. eGFP:CPCPsV was observed in the cytoplasm of healthy citrus, similar to the pattern found in one of the few reports for cytosolic GFP (Cy-GFP)

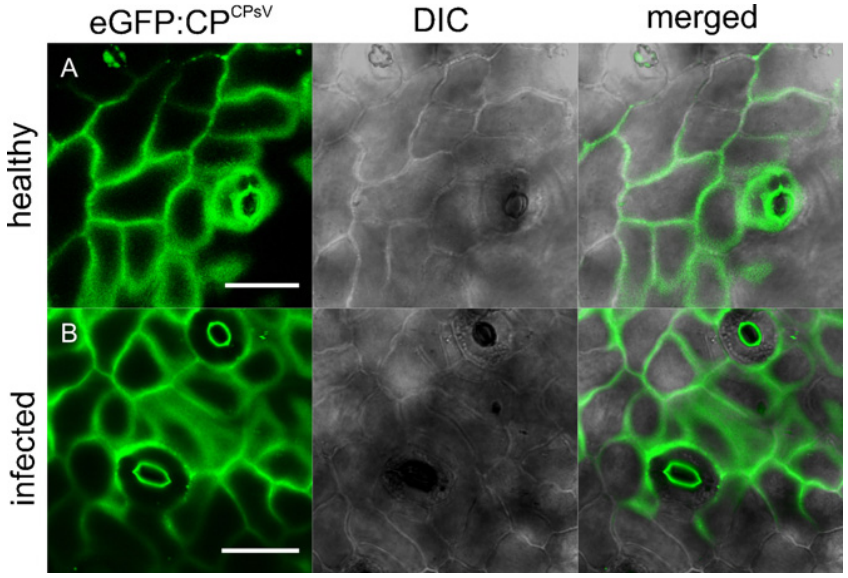

Fig. 5. Subcellular localization of eGFP:CPCPsV in $C$. sinensis epidermal cells. eGFP:CPCPsV expression at 7 dpai in (A) healthy and (B) CPsV-infected tissue. Scale bar $=20 \mu \mathrm{m}$.

(Xu et al., 2011) (Fig. 5A). In symptomatic regions of infected citrus leaves, where the virus has accumulated, the same localization was observed (Fig. 5B), indicating that the $\mathrm{CP}$ maintains its cytoplasmic localization during the course of infection.

\subsection{The $C P^{C P S V}$ and $C P^{M i L B V V}$ show homologous and heterologous interactions}

In CPsV and MiLBVV virus particles the $\mathrm{CP}$ subunits may interact among themselves and with the viral RNAs to encapsidate the viral genome. To test for in vivo interactions between the $\mathrm{CP}$ molecules we expressed the proteins in the absence of viral RNA and measured FRET between $\mathrm{CP}^{\mathrm{CPs}}$ : $\mathrm{eGFP}$ and $\mathrm{CP}^{\mathrm{CPsV}}$ :mRFP by FLIM. When expressed alone, the fluorescence lifetime for $\mathrm{CP}^{\mathrm{CPSV}}$ :eGFP was $2.36 \mathrm{~ns}(\mathrm{SD}=0.07 ; N=25)$ (Fig. $6 \mathrm{~A}$ and $\mathrm{E}$ ) and did not change significantly $(p<0.01)$ upon co-expression with free mRFP (2.37 ns; $\mathrm{SD}=0.07 ; N=21$ ) (Fig. $6 \mathrm{~B}$ and E). However, when $\mathrm{CP}^{\mathrm{CP} s \mathrm{~V}}$ :eGFP was co-expressed with $\mathrm{CP}^{\mathrm{CPV} V}: \mathrm{mRFP}$, the fluorescence lifetime was significantly reduced to $2.1 \mathrm{~ns}(\mathrm{SD}=0.1 ; N=24, p<0.01)$ indicating a FRET efficiency of $11 \%$ (Fig. $6 \mathrm{C}$ and $\mathrm{E}$ ). This demonstrates that $\mathrm{CP} C \mathrm{PsV}$ molecules occur in close molecular proximity, which is indicative of their interaction in the cytoplasm. Using eGFP:CPCPsV instead of $\mathrm{CP}^{\mathrm{CPsV}}$ :eGFP prevented FRET interactions with $\mathrm{CP}^{\mathrm{CPsV}}$ :mRFP thus showing that an eGFP fusion to the N-terminus of $\mathrm{CP}^{\mathrm{CPs} V}$ interferes with CP:CP interactions (data not shown). The same assay was conducted for $\mathrm{CP}^{\mathrm{MiLBVV}}$, providing evidence that also the CP of MiLBVV undergoes homologous interactions in the cytoplasm (10\% of FRET efficiency; Fig. S3). To test whether the CPs of the two different viruses are able to interact and form heteromeric complexes, we expressed $\mathrm{CP}^{\mathrm{CPsV}}: \mathrm{eGFP}$ together with $\mathrm{CP}^{\mathrm{MiLBVV}}: \mathrm{mRFP}$. In the presence of $C P^{M i L B V V}: m R F P$ the fluorescence lifetime of $C P^{C P V}: \mathrm{eGFP}$ was $2.25 \mathrm{~ns}(\mathrm{SD}=0.06 ; N=18)$ and significantly different $(p<0.01)$ to the fluorescence lifetime of the protein when expressed alone, revealing a 5\% of FRET efficiency (Fig. $6 \mathrm{D}$ and E).

Further evidence supporting $\mathrm{CP}-\mathrm{CP}$ interactions were obtained by co-immunoprecipitation assays employing the RFP-Trap (Chromotek, Germany). As is shown in Fig. 7, the coexpression of $\mathrm{CP}^{\mathrm{CPsV}}: \mathrm{eGFP}$ or CPMiLBVV $:$ eGFP with mRFP allowed the detection of the $76 \mathrm{kDa}$ fusion-proteins with anti-GFP antibody (lanes I, panels $A$ and B). However, no CP-eGFP signal was obtained in the bound extract (lanes B, panels A and B). When blotted with anti-RFP antibody the expected band of $26 \mathrm{kDa}$ for mRFP was detected (lanes I and $B$, panels $A$ and $B$ ) indicating that there is no unspecific binding of the CPs to mRFP. 

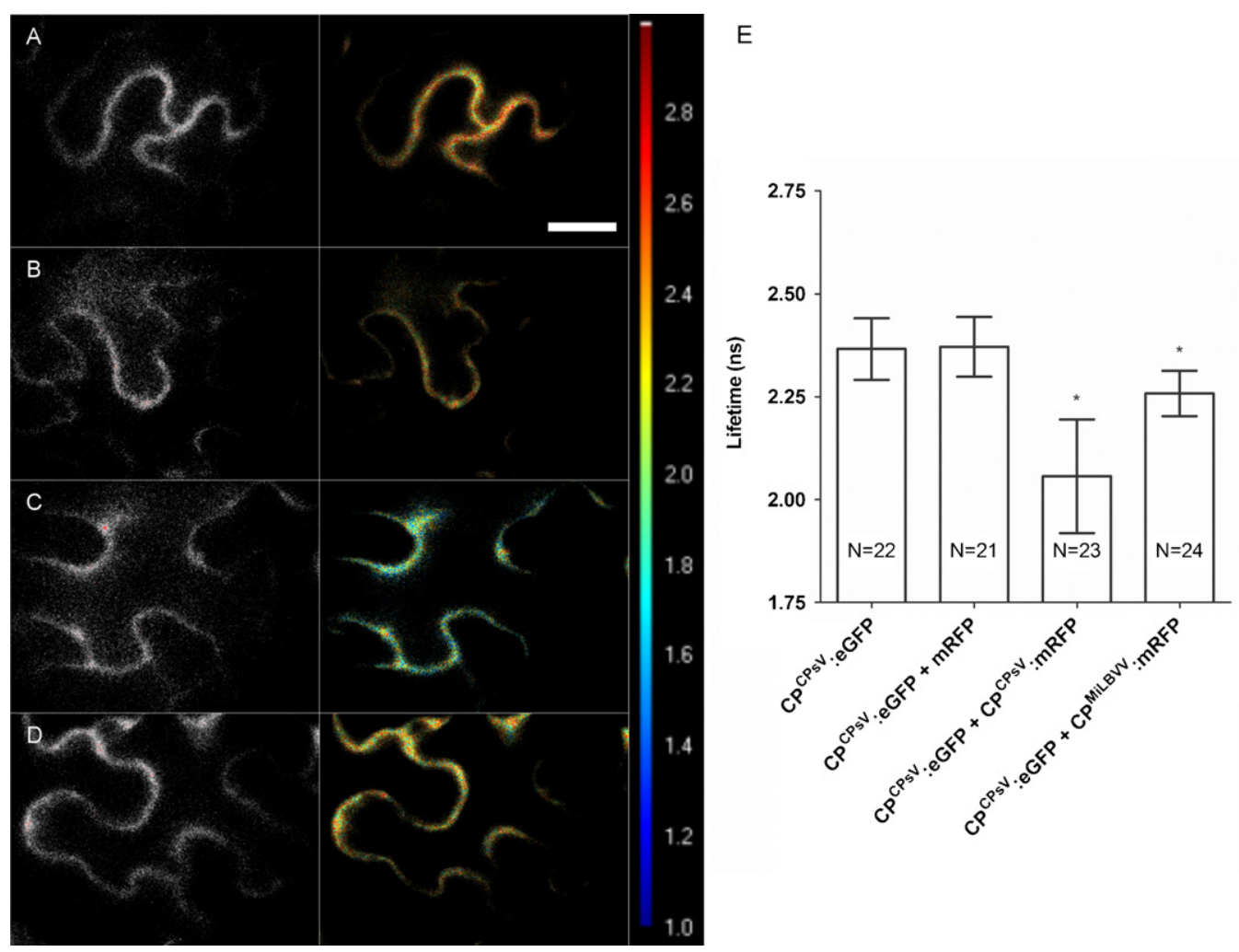

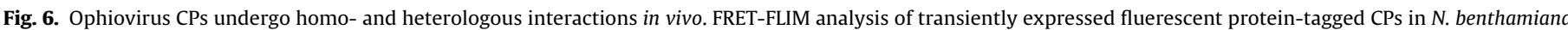

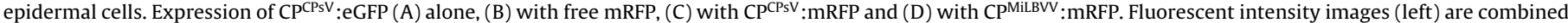

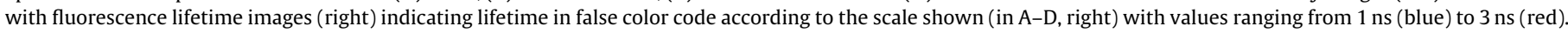

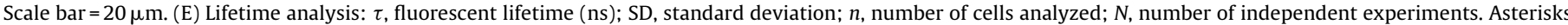

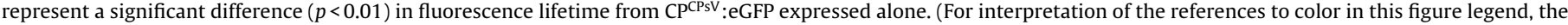
reader is referred to the web version of the article.)

Homologous interaction between $\mathrm{CPCPsV}$ molecules was observed by co-expression of $\mathrm{CP}^{\mathrm{CPsV}}$ :eGFP and $\mathrm{CP}^{\mathrm{CPsV}}$ :mRFP and their detection in the bound extracts with anti-GFP and anti-RFP, respectively (see lanes $B$ and $I$, panel $A$ ). When the same assay was carried out with $\mathrm{CP}^{\mathrm{MiLBVV}}$, a homologous $\mathrm{CP}-\mathrm{CP}$ interaction was again observed (see lanes B and I, panel B). Heterologous interactions between $C P^{C P s V}$ and $C P^{\text {MiLBVV }}$ were observed by

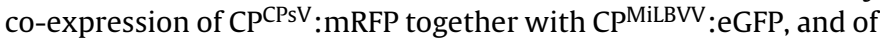
$\mathrm{CP}^{\mathrm{MiLBVV}}$ :mRFP together with $\mathrm{CP}^{\mathrm{CPsV}}$ :eGFP. These fusion-protein combinations were detected with anti-GFP and anti-RFP in the bound extracts (lanes $\mathrm{B}$, panel $\mathrm{C}$ ) indicating specific interactions.

The results of the co-precipitation experiments are consistent with the results obtained by FLIM and indicate that the CPs of CPsV and MiLBVV occur in close proximity and can undergo both homo- and heterologous interactions in vivo. The formation of hetero-oligomers suggests that these proteins may share specific conserved domains for oligomerization.

\subsection{Conserved motifs are present in all ophioviruses coat proteins}

Bioinformatic analysis of the CPMiLBVV amino acid sequence revealed the presence of a leucine zipper motif with four heptad repeats at position 252-273. Alignment of this sequence to other ophiovirus CP sequences (Fig. 8A) indicates that this motif is conserved, whereby the first and the third leucine residues (" $L$ " in $d$ position of the helical wheel representation) are conserved among all ophioviruses CPs and the second and fourth Ls are less conserved, with changes of L for F, K, or V. According to Krylov and Vinson (Krylov and Vinson, 2001), the $\mathrm{L} \rightarrow \mathrm{K}$ change, only found in $\mathrm{CP}^{\mathrm{CPsV}}$, could affect the structure of the leucine zipper. However, the leucine zipper structure could be stabilized by two extra heptads present at the N-terminal end of this motif. As is shown in Fig. 8B, the helical wheel diagrams of the leucine zipper motif in different ophiovirus CPs exhibit charged and polar groups at e and g positions, which could stabilize dimer formation through $\mathrm{e}-\mathrm{g}^{\prime}$ and $\mathrm{g}-\mathrm{e}^{\prime}$ interactions (O'Shea et al., 1989). In the case of $\mathrm{CP}^{\mathrm{CPSV}}$ and $C \mathrm{P}^{\mathrm{MiLBVV}}$, it could be speculated that these two $\alpha$-helices are able to interact, consistent with the FLIM-FRET and immunoprecipitation results.

Positively charged amino acids are frequently involved in nucleic acid binding properties of proteins (Chen and Varani, 2005; Weiss and Narayana, 1998). Towards the C-terminal end of all ophiovirus CPs there is a conserved SRCK tetrapeptide motif containing two basic amino acids (Fig. 8A). This motif could be involved in the interaction with RNA, as reported for the coat proteins of other plant and animal viruses (Citovsky et al., 1990; Venter et al., 2009).

\section{Discussion}

Characterization of the ophiovirus CPs contributes to our basic knowledge about this family of multipartite negative viruses. Determining the subcellular localization of plant virus-encoded proteins provides information about the roles and functions of the proteins during virus infection. So far, immunolocalization experiments to detect the $\mathrm{CP}^{\mathrm{CPsV}}$ in thin sections of infected tissue have not been successful (Robert G. Milne, IVV, Torino, Italy and Elliot W. Kitajima, Piracicaba, Brazil, personal communications), probably because the virion accumulation is much lower compared to RWMV, which has been detected in the cytoplasm of infected tissues (Vaira et al., 1997). Given this difficulty, we studied the 
A
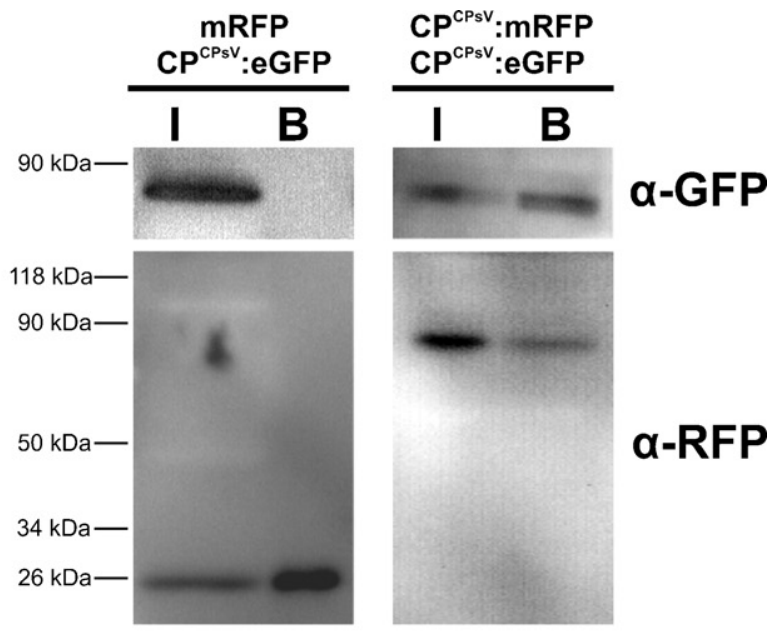

B
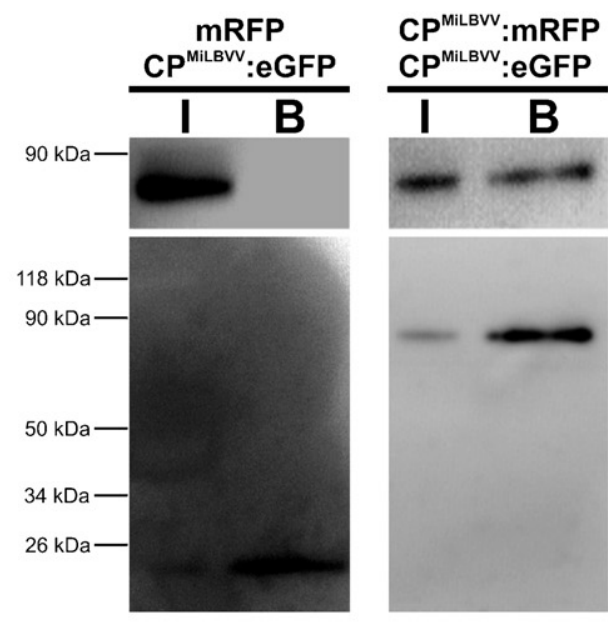

$\alpha$-GFP
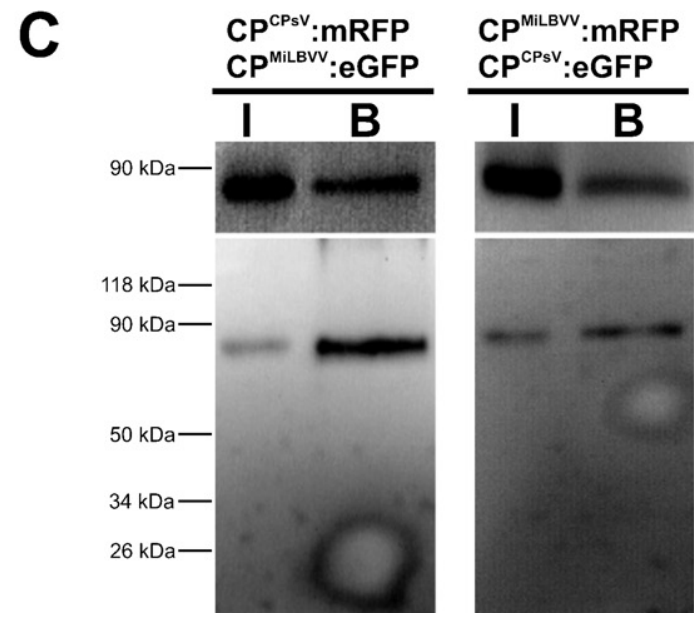

Fig. 7. Confirmation of homo- and heterologous interactions between the ophiovirus CPs by Co-Immunoprecipitation. After immunoprecipitation with mRFPtrap, input (I) and bound (B) fractions were separated by SDS-PAGE and analyzed by immunoblot analysis using anti-GFP ((-GFP) or anti-RFP ((-RFP). Interactions tested: (A) CPCPS $:$ eGFP with mRFP (left) and with $\mathrm{CP}^{\mathrm{CPsV}}: \mathrm{mRFP}$ (right); (B) CPMiLBVV: eGFP with mRFP (left) and with CPMiLBVV:mRFP (right); (C) CPCPsV :eGFP with $C^{M i L B V V}: m R F P($ left $)$ and $C^{C P s V}:$ mRFP with CPMiLBVV : eGFP (right). Molecular weights are indicated to the left. CP:eGFP and CP:mRFP: $76 \mathrm{kDa}$, mRFP: $26 \mathrm{kDa}$ subcellular localization of CPsV and MiLBVV coat proteins by different methods (cell fractionation, transient expression) using specific hosts. Our results indicate that in natural and experimental hosts, in the context of the infection or upon transient or stable expression in $N$. benthamiana, the $\mathrm{CP}^{\mathrm{CPSV}}$ was always found as soluble protein in the cytoplasm. The same localization was also found for $\mathrm{CP}^{\mathrm{MiLBVV}}$, suggesting that virion assembly of these two ophioviruses and RWMV occurs in the cytoplasm.

Previous studies addressing the nucleocapsid protein (N protein) of the tenuivirus Rice stripe virus (Liang et al., 2005) or the tospovirus Tomato spotted wilt virus (TSWV), two other members of plant negative RNA viruses, have demonstrated that the $\mathrm{N}$ protein forms aggregates in the cytoplasm, and homodimerization of $\mathrm{N}$ protein and $\mathrm{N}$ oligomerization in large aggregates was confirmed by FRET measurements (Ribeiro et al., 2009). Applying the same methodology and including co-immunoprecipitation, we found here homologous and heterologous in vivo interactions for the CPs of CPsV and MiLBVV. These interactions involve soluble proteins in the cytoplasm, without prior formation of coat protein aggregates. Homologous interaction correlates with the images of electron micrographs of ophiovirus particles showing small CP subunits embracing the RNA like a ring (Robert G. Milne, 2007, personal communication).

Although our observations indicate that the CPs of CPsV and MiLBVV can interact in vivo upon co-expression, this does not seem to play a role in nature since the two viruses do not occur in the same host. However, if other ophioviruses do share the same host, synergistic interactions between different CPs could play a role. In this respect, it could be important to search for interaction between the CPs of MiLBVV and Lettuce big-vein associated virus (LBVaV), a varicosavirus always presents in lettuce plants infected with MiLBVV (Natsuaki et al., 2002; Roggero et al., 2003). On the other hand, although the virus species in the family Ophioviridae are grouped into only one genus, Ophiovirus, it appears likely that this genus is rather heterogenous and that different genera may be separated as soon as more information about genome expression, protein function, and vector-transmission were available. Comparison of CPs, based on the analysis of serological relationship, is one criterion to look for relationships among different species. These have placed CPsV far from the other members of the Ophioviridae family (Roggero et al., 2000). Our observa-

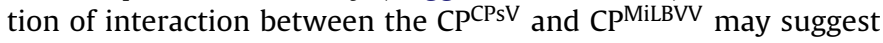
that the analysis of in vivo interactions could be used as a new approach to investigate relationships among members of this family.

Bioinformatic analysis of ophioviruses $\mathrm{CP}$ sequences revealed the presence of conserved leucine repeats. Such repeats play a role in protein-protein interactions and are implicated in critical protein functions. Leucine repeat domains have been described in eukaryotic transcription factors and later also in viral proteins. For example, the p7 movement protein of Pelargonium flower break virus (PFBV) contains a leucine zipper like motif that is essential for virus infectivity in plants (Martinez-Turino and Hernandez, 2011). Another example is the Herpes simplex virus (HSV-1) UL6 protein. The integrity of the leucine zipper region of this protein is required for protein oligomerisation, portal ring formation, and genome encapsidation (Nellissery et al., 2007; Newcomb et al., 2001). As reported in several cases, the leucine residues are critical for protein dimerization and DNA binding (O'Shea et al., 1989). For example, the homodimerization of the non-structural protein NS4B of Hepatitis $C$ virus is facilitated by the amino-terminal part containing a basic ZIP motif (Welker et al., 2010). Another example is the basic ZIP-like domain of the Human cytomegalovirus (HCMV) pUL71 protein which is required for protein oligomerization, virion egress and secondary envelopment leading to infectious viral particles (Meissner et al., 2012). 

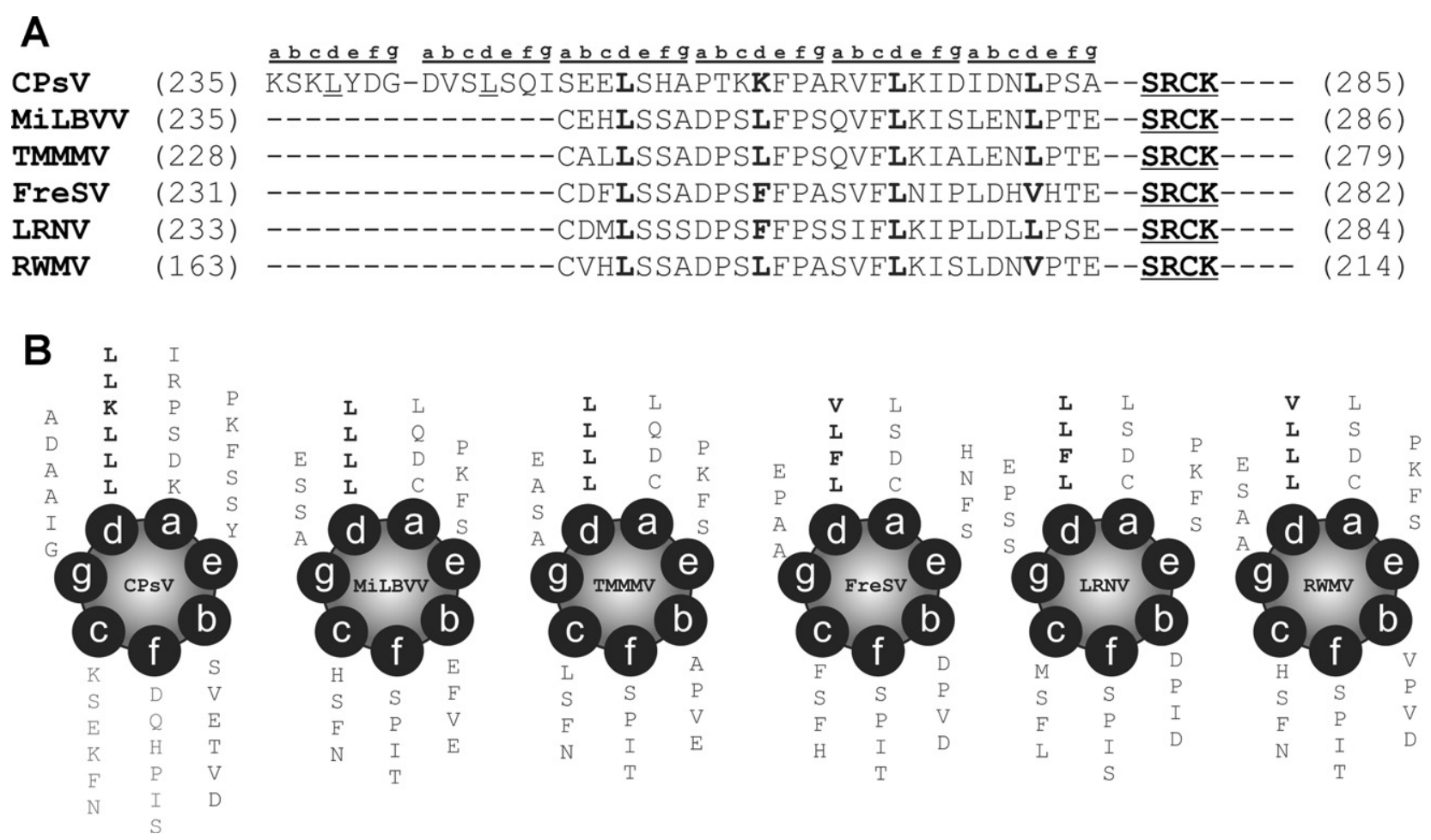

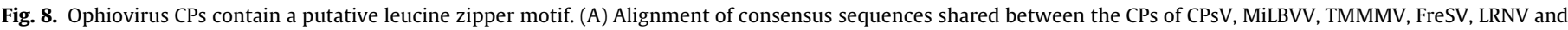

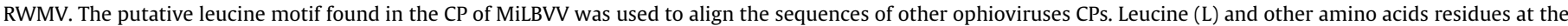

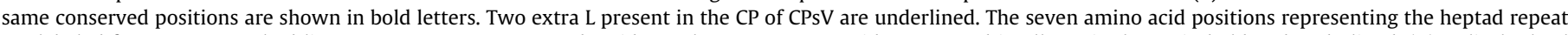

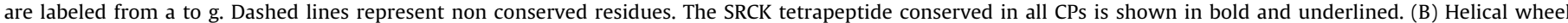
representation of each ophiovirus $\mathrm{CP}$ sequence. Residues of the heptad repeats are numbered as in panel A.

Viral coat proteins can have non-structural functions such as in cell-to-cell/long distance movement or virus-vector interaction. In this respect, MiLBVV, LRNV and FreSV are borne-transmitted, and some conserved epitopes of their capsid proteins could be involved in the interaction with the zoospores of Olpidium brasicae. It has been reported that Cucumber necrosis virus, transmitted by Olpidium bornovanus, has specific sites on the capsid that bind to the zoospores (Rochon et al., 2004).

This work describes the subcellular localization of ophiovirus CPs and CP-CP interactions probably mediated by a leucine zipper domain and could open further studies of coat protein functions as a structural protein, Site-directed mutagenesis applied to the conserved leucine repeats and to the SRCK tetrapeptide could reveal the biological significance of these amino acid sequences with respect to ophioviruses particle structure and assembly.

\section{Acknowledgements}

We thank the Functional Genomics Division of the Department of Plant Systems Biology at the VIB-Ghent University for providing plasmids pB7FWG2, pB7RWG2 and pB7WGF2, M.M. Goodin for providing the pGD vector, and EW Kitajima for the immuno TEM. M.L. García, Gabriel Robles Luna and Carina A. Reyes belong to the staff of Departamento de Ciencias Biológicas, Facultad de Ciencias Exactas UNLP, Maria Laura Garcia and C.A. Reyes are researchers of CONICET, and G. Robles Luna is a fellow of CONICET. This work was supported by the ANPCyT and the CONICET (grants PICT 11714, PICT 32359 and PIP 6108). The authors thank the EMBO for financial support through a short-term fellowship to Gabriel Robles Luna. Work in the laboratory of M. Heinlein at the IBMP in Strasbourg was performed with financial support by the CNRS and the ANR (grant ANR-08-BLAN-0244).

\section{Appendix A. Supplementary data}

Supplementary data associated with this article can be found, in the online version, at http://dx.doi.org/10.1016/j.virusres. 2012.08.005.

\section{References}

Anderson, C., 2000. Presentation on the Argentinean certification program. In: GCGN Meeting, http://www.crec.ifas.ufl.edu/societies/ISC/gcgn/WG_3.PDF

Barcala Tabarrozzi, A.E., Peña, E.J., Dal Bo, E., Robles Luna, G., Reyes, C.A., Garcia, M.L., 2010. Identification of Mirafiori lettuce big-vein virus and Lettuce big-vein associated virus infecting Lactuca sativa with symptoms of lettuce big-vein disease in Argentina. Plant Pathology 59 (6), 1160-1161.

Bos, L., Huijberts, N., 1996. Lettuce ring necrosis, caused by a chytrid-borne agent distinct from Lettuce big-vein virus. European Journal of Plant Pathology 102, 867-873.

Boutant, E., Didier, P., Niehl, A., Mely, Y., Ritzenthaler, C., Heinlein, M., 2010. Fluorescent protein recruitment assay for demonstration and analysis of in vivo protein interactions in plant cells and its application to Tobacco mosaic virus movement protein. Plant Journal 62 (1), 171-177.

Campiglia, H.G., Silveira, C.M., Salibe, A.A., 1976. Psorosis transmission through seeds of trifoliate orange. In: 7th Conference of the International Organization of Citrus Virologists, IOCV, pp. 132-134.

Citovsky, V., Knorr, D., Schuster, G., Zambryski, P., 1990. The P30 movement protein of Tobacco mosaic virus is a single-strand nucleic acid binding protein. Cell 60 (4), 637-647.

Chen, Y., Varani, G., 2005. Protein families and RNA recognition. FEBS Journal 272 (9), 2088-2097.

Danós, E., 1990. La psorosis de los citricos: la epidemia en curso en Argentina y el desafio de su control. Revista de Investigaciones Agropecuarias, 265-277.

Falk, B.W., 1997. Lettuce big-vein. In: Davis, R.M., Subbarao, K.V., Raid, R.N., Kurtz, E.A. (Eds.), Compendium of Lettuce Diseases. APS Press, St. Paul, pp. 41-42.

Garcia, M.L., Dal Bo, E., Grau, O., Milne, R.G., 1994. The closely related citrus ringspot and citrus psorosis viruses have particles of novel filamentous morphology. Journal of General Virology 75 (Pt. 12), 3585-3590.

Garnsey, S.M., Timmer, L.W., 1980. Mechanical transmissibility of citrus ringspot virus isolates from Florida, Texas, and California. In: Calavan, E.C., Garnsey, S.M. Timmer, L.W. (Eds.), Proc. of the 8th Conf. of the IOCV. Riverside, CA, USA. 
Goodin, M.M., Dietzgen, R.G., Schichnes, D., Ruzin, S., Jackson, A.O., 2002. pGD vec tors: versatile tools for the expression of green and red fluorescent protein fusions in agroinfiltrated plant leaves. Plant Journal 31 (3), 375-383.

Horsch, R.B., Fry, J.E., Hoffmann, N.L., Eichholtz, D., Rogers, S.G., Fraley, R.T., 1985. A simple and general method for transferring genes into plants. Science 227 (4691), 1229-1231.

Hulo, N., Bairoch, A., Bulliard, V., Cerutti, L., Cuche, B.A., de Castro, E., Lachaize, C., Langendijk-Genevaux, P.S., Sigrist, C.J., 2008. The 20 years of PROSITE. Nucleic Acids Research 36, D245-D249 (Database issue).

Karimi, M., Inze, D., Depicker, A., 2002. GATEWAY vectors for Agrobacteriummediated plant transformation. Trends in Plant Science 7 (5), 193-195.

Krylov, D., Vinson, C.R., 2001. Leucine Zipper, eLS. John Wiley \& Sons, Ltd, Chichester, WK.

Liang, D., Qu, Z., Ma, X., Hull, R., 2005. Detection and localization of Rice stripe virus gene products in vivo. Virus Genes 31 (2), 211-221.

Lot, H., Campbell, R.N., Souche, S., Milne, R.G., Roggero, P., 2002. Transmission by Olpidium brassicae of Mirafiori lettuce virus and Lettuce big-vein virus, and their roles in lettuce big-vein etiology. Phytopathology 92 (3), 288-293.

Martinez-Turino, S., Hernandez, C., 2011. A membrane-associated movement protein of Pelargonium flower break virus shows RNA-binding activity and contains a biologically relevant leucine zipper-like motif. Virology 413 (2), 310-319.

Meissner, C.S., Suffner, S., Schauflinger, M., von Einem, J., Bogner, E., 2012. A leucine zipper motif of a tegument protein triggers final envelopment of Human cytomegalovirus. Journal of Virology 86 (6), 3370-3382.

Milne, R.G., Garcia, M.L., Moreno, P., 2003. Citrus Psorosis virus. Association of Applied Biologists (AAB) Descriptions of Plant Viruses, Harpenden, UK, http://www.dpvweb.net/dpv/showdpv.php?dpvno=401

Morikawa, T., Nomura, Y., Yamamoto, T., Natsuaki, T., 1995. Partial characterization of virus-like particles associated with tulip mild mottle mosaic. Annals of the Phytopathological Society of Japan 61, 578-581.

Nakagawa, T., Kurose, T., Hino, T., Tanaka, K., Kawamukai, M., Niwa, Y., Toyooka, K., Matsuoka, K., Jinbo, T., Kimura, T., 2007. Development of series of gateway binary vectors, pGWBs, for realizing efficient construction of fusion genes for plant transformation. Journal of Bioscience and Bioengineering 104 (1), 34-41.

Nakai, K., Horton, P., 1999. PSORT: a program for detecting sorting signals in protein and predicting their subcellular localization. Trends in Biochemical Sciences 24 (1), 34-36.

Natsuaki, K.T., Morikawa, T., Natsuaki, T., Okuda, S., 2002. Mirafiori lettuce virus detected from lettuce with big vein symptoms in Japan. Japanese Journal of Phytopathology 68, 309-312.

Naum-Ongania, G., Gago-Zachert, S., Peña, E., Grau, O., Garcia, M.L., 2003. Citrus psorosis virus RNA 1 is of negative polarity and potentially encodes in its complementary strand a $24 \mathrm{~K}$ protein of unknown function and $280 \mathrm{~K}$ putative RNA dependent RNA polymerase. Virus Research 96 (1-2), 49-61.

Nellissery, J.K., Szczepaniak, R., Lamberti, C., Weller, S.K., 2007. A putative leucine zipper within the Herpes simplex virus type 1 UL6 protein is required for portal ring formation. Journal of Virology 81 (17), 8868-8877.

Newcomb, W.W., Juhas, R.M., Thomsen, D.R., Homa, F.L., Burch, A.D., Weller, S.K. Brown, J.C., 2001. The UL6 gene product forms the portal for entry of DNA into the Herpes simplex virus capsid. Journal of Virology 75 (22), 10923-10932.

O'Shea, E.K., Rutkowski, R., Kim, P.S., 1989. Evidence that the leucine zipper is a coiled coil. Science $243,538-542$

Pagni, M., Ioannidis, V., Cerutti, L., Zahn-Zabal, M., Jongeneel, C.V., Hau, J., Martin O., Kuznetsov, D., Falquet, L., 2007. MyHits: improvements to an interactive resource for analyzing protein sequences. Nucleic Acids Research 35 W433-W437 (Web Server issue).

Ribeiro, D., Borst, J.W., Goldbach, R., Kormelink, R., 2009. Tomato spotted wilt virus nucleocapsid protein interacts with both viral glycoproteins $\mathrm{Gn}$ and Gc in planta. Virology 383 (1), 121-130.

Rochon, D., Kakani, K., Robbins, M., Reade, R., 2004. Molecular aspects of plant virus transmission by Olpidium and plasmodiophorid vectors. Annual Review of Phytopathology 42, 211-241.

Rodriguez-Cerezo, E., Findlay, K., Shawn, J.G., Lomonossoff, G.P., Qiu, S.G., Linstead, P., Shanks, M., Risco, C., 1997. The coat and cylindrical inclusion poteins of a potyvirus are associated with connections between plant cells. Virology 236 (2), 296-306.

Roggero, P., Ciuffo, M., Vaira, A.M., Accotto, G.P., Masenga, V., Milne, R.G., 2000. An Ophiovirus isolated from lettuce with big-vein symptoms. Archives of Virology 145 (12), 2629-2642.

Roggero, P., Lot, H., Souche, S., Lenzi, R., Milne, R.G., 2003. Occurrence of Mirafiori lettuce virus and Lettuce big-vein virus in relation to development of big-vein symptoms in lettuce crops. European Journal of Plant Pathology 109, 261-267.

Roistacher, C.N., 1991. Graft-Transmissible Diseases of Citrus. In: Handbook for Detection and Diagnosis. Food and Agriculture Organization of the United Nations, Rome, Italy, pp. 115-126.

Roistacher, C.N., 1993. Psorosis - a review. In: 12th Conf. International Org Citrus Virol, IOCV, pp. 139-162.

Rouleau, M., Bancroft, J.B., Mackie, G.A., 1993. Partial purification and characterization of foxtail mosaic potexvirus RNA-dependent RNA polymerase. Virology 197 (2), 695-703.

Rouleau, M., Smith, R.J., Bancroft, J.B., Mackie, G.A., 1995. Subcellular inmunolocalization of the coat protein of two potexviruses in infected Chenopodium quinoa. Virology 214 (1), 314-318.

Ruiz, M.T., Voinnet, O., Baulcombe, D.C., 1998. Initiation and maintenance of virusinduced gene silencing. The Plant Cell 10 (6), 937-946.

Sanchez de la Torre, E., Riva, O., Zandomeni, R., Grau, O., García, M.L., 1998. The top component of Citrus psorosis virus contains two ssRNAs, the smaller encodes the coat protein. Molecular Plant Pathology On-Line, http://www.bspp.org.uk/ mppol/1998/0929rybicki

Sanchez de la Torre, M.E., Lopez, C., Grau, O., Garcia, M.L., 2002. RNA 2 of Citrus psorosis virus is of negative polarity and has a single open reading frame in its complementary strand. Journal of General Virology 83 (Pt 7), 1777-1781.

Tamura, K., Dudley, J., Nei, M., Kumar, S., 2007. MEGA4: Molecular Evolutionary Genetics Analysis (MEGA) software version 4.0. Molecular Biology and Evolution 24 (8), 1596-1599.

Torok, V.A., Vetten, H.J., 2004. Characterization and genome organization of a new ophiovirus associated with lettuce ring necrosis. Unpublished.

Vaira, A.M., Milne, R.G., Accotto, G.P., Luisoni, E., Masenga, V., Lisa, V., 1997. Partial characterization of a new virus from ranunculus with a divided RNA genome and circular supercoiled thread-like particles. Archives of Virology 142 (11), 2131-2146.

van der Wilk, F., Dullemans, A.M., Verbeek, M., van den Heuvel, J.F., 2002. Nucleotide sequence and genomic organization of an ophiovirus associated with lettuce big-vein disease. Journal of General Virology 83 (Pt. 11), 2869-2877.

van Dorst, H.J.M., 1975. Evidence for the soil-borne nature of Freesia leaf necrosis virus. Netherlands Journal of Plant Pathology 81, 45-48.

Venter, P.A., Marshall, D., Schneemann, A., 2009. Dual roles for an arginine-rich motif in specific genome recognition and localization of viral coat protein to RNA replication sites in flock house virus-infected cells. Journal of Virology 83 (7) 2872-2882.

Weiss, M.A., Narayana, N., 1998. RNA recognition by arginine-rich peptide motifs. Biopolymers 48 (2-3), 167-180.

Welker, M.W., Welsch, C., Meyer, A., Antes, I., Albrecht, M., Forestier, N., Kronenberger, B., Lengauer, T., Piiper, A., Zeuzem, S., Sarrazin, C., 2010. Dimerization of the hepatitis $C$ virus nonstructural protein $4 B$ depends on the integrity of an aminoterminal basic leucine zipper. Protein Science 19 (7), 1327-1336.

Xu, S., Cai, X., Tan, B., Guo, W., 2011. Comparison of expression of three different sub-cellular targeted GFPs in transgenic Valencia sweet orange by confocal laser scanning microscopy. Plant Cell, Tissue and Organ Culture 104 199-207.

Zanek, M.C., Peña, E., Reyes, C.A., Figueroa, J., Stein, B., Grau, O., Garcia, M.L., 2006. Detection of Citrus psorosis virus in the northwestern citrus production area of Argentina by using an improved TAS-ELISA. Journal of Virological Methods 137 (2), 245-251.

Zanek, M.C., Reyes, C.A., Cervera, M., Peña, E.J., Velazquez, K., Costa, N., Plata, M.I., Grau, O., Pena, L., Garcia, M.L., 2008. Genetic transformation of sweet orange with the coat protein gene of Citrus psorosis virus and evaluation of resistance against the virus. Plant Cell Reports 27 (1), 57-66. 